\title{
TURKUSOWE LAKE (WOLIN ISLAND, POLAND) - SURFACE WATERS QUALITY CHANGES IN YEARS 1986-2010
}

\author{
JEZIORO TURKUSOWE (WYSPA WOLIN, POLSKA) - \\ ZMIANY JAKOŚCI WÓD POWIERZCHNIOWYCH W LATACH 1986-2010
}

\begin{abstract}
After presentation of the characteristics of a water reservoir in $\mathrm{CaCO}_{3}$ excavation pit, called the Turkusowe Lake, situated in the Wolin National Park on the Wolin Island, available results of the analyses referring to the quality of surface water of this water reservoir and being carried out since 1986 as well as those of own studies being carried out from 1999 to 2010 were gathered, collecting this way a research material covering the quarter-century 1986-2010. It was shown that the Turkusowe Lake is a water reservoir being resistant by nature to eutrophication (lake basin development and depth, surrounding by the heights adhering to it, and presence of $\mathrm{CaCO}_{3}$ building the lake basin), whereas an increase in the trophic level and development of eutrophication phenomena in the form of weak phytoplankton blooms being observed, particularly in 2005-2010, is connected with increased anthropogenic pressure in the form of direct discharge of municipal sewage to the lake and waste-water to the soil in the alimentation zone of underground waters feeding this lake. The extent of anthropogenic pressure was so big that it started to prevail over the natural processes limiting an increase in the trophic level in this lake.
\end{abstract}

Keywords: lakes, trophic level and eutrophication, chalk lakes, Turkusowe Lake, Wolin National Park

\section{Introduction}

The investigations of hydrogeochemical processes proceeding in natural waters which remain in contact with the subsoil rich in calcium carbonate remain still scientifically interesting investigations, $e g$ when it means about investigation of mountain streams waters, which flow down stream channel contains in rock material $\mathrm{CaCO}_{3}$ [1], and also investigative of young (of several score years) water reservoirs which arise in inundate of water open chalk and limestone excavation pits. On moraine upland areas in Western Pomerania in Poland are two such water reservoirs, particularly the Turkusowe Lake in the Wolin National Park on the Wolin Island and the Szmaragdowe Lake in the Szczecin Landscape

\footnotetext{
${ }^{1}$ Department of Chemistry and Natural Waters Management, Faculty of Biology, Szczecin University, ul. Felczaka 3C, 71-412 Szczecin, Poland, phone +48 914441571

${ }^{2}$ Department of Veterinary Public Health and Welfare, Faculty of Veterinary Hygiene and Ecology, University of Veterinary and Pharmaceutical Sciences Brno, Palackeho tr. 1/3, 61242 Brno, Czech Republic

*Corresponding author: polesz@univ.szczecin.pl
} 
Park "Puszcza Bukowa" adjoining the Szczecin-Zdroje District in Szczecin. Both reservoirs are specific lakes and similar to each other (Table 1, Fig. 1). Their lake bowls are surrounded by hills directly adjacent to lakes with very steep slopes surrounding the lake on three sides. The only difference is that the Turkusowe Lake is available only from the north, and Szamaragdowe Lake - accessible only from the south. They are young lakes, approximately 75 and 90 years, respectively, the waters of which were characterised by low trophic level, which was generally attributed to specific resistance of the ecosystems of these lakes to eutrophication [2-5], which is connect witch presence of formative pan lake $\mathrm{CaCO}_{3}$ able to fixing (chemisorption) phosphorus compounds, and the same reduction of trophy of water [2]. For what can speak a very low concentration of phosphorus in the waters of these lakes [3, 4].

Morphometric data of Turkusowe Lake in Wolin National Park and Szmaragdowe Lake in Szczecin

\begin{tabular}{|c|c|c|c|c|}
\hline No & Indicators & Turkusowe Lake & \multicolumn{2}{|c|}{ Szmaragdowe Lake } \\
\hline \multicolumn{5}{|c|}{ Geographical location } \\
\hline 1 & Geographical longitude & $14^{\circ} 26^{\prime} 20^{\prime \prime} \mathrm{E}^{1}$ & \multicolumn{2}{|c|}{$14^{\circ} 37^{\prime} 30^{\prime \prime} \mathrm{E}^{3}$} \\
\hline 2 & Geographical latitude & $53^{\circ} 52^{\prime} 37^{\prime} \mathrm{N}^{1}$ & \multicolumn{2}{|c|}{$53^{\circ} 22^{\prime} 17^{\prime \prime} \mathrm{N}^{3}$} \\
\hline \multicolumn{5}{|c|}{ Parameters characterizing surface of lake } \\
\hline 3 & Area $\left[\mathrm{m}^{2}\right]$ & $55700^{1}$ & $26000^{3}$ & $25000^{4}$ \\
\hline 4 & Length $[\mathrm{m}]$ & $430.0^{1}$ & $255.2^{5}$ & $275.0^{4}$ \\
\hline 5 & Width [m] & $246.0^{1}$ & $159.2^{5}$ & $150.0^{4}$ \\
\hline 6 & Average width $[\mathrm{m}]$ & $129.5^{1}$ & \multicolumn{2}{|c|}{$101.8^{5}$} \\
\hline 7 & Coefficient of extension lake ${ }^{6}$ & $3.32^{1}$ & \multicolumn{2}{|c|}{$2.51^{5}$} \\
\hline 8 & Length of shoreline $[\mathrm{km}]$ & $1.05^{1}$ & \multicolumn{2}{|c|}{$0.79^{5}$} \\
\hline 9 & Development of shoreline $^{7}$ & $1.26^{1}$ & \multicolumn{2}{|c|}{$1.38^{3}$} \\
\hline \multicolumn{5}{|c|}{ Parameters characterizing basin of lake } \\
\hline 10 & Capacity $\left[\mathrm{m}^{3}\right]$ & $513705.3^{1}$ & \multicolumn{2}{|c|}{$214333.0^{5}$} \\
\hline 11 & Max. depth [m] & $21.2^{1}$ & \multicolumn{2}{|c|}{$15.8^{3}$} \\
\hline 12 & Average depth ${ }^{8}[\mathrm{~m}]$ & $9.2^{1}$ & \multicolumn{2}{|c|}{$8.2^{3}$} \\
\hline 13 & Relatively depth $^{9}$ & $0.0898^{1}$ & \multicolumn{2}{|c|}{$0.0979^{5}$} \\
\hline 14 & Coefficient of depth ${ }^{10}$ & $0.43^{1}$ & \multicolumn{2}{|c|}{$0.52^{3}$} \\
\hline 15 & Crypto depression [m] & $18.6^{1}$ & \multicolumn{2}{|c|}{-} \\
\hline
\end{tabular}

Notations: ${ }^{1}[3], \quad{ }^{2}$ http://pl.wikipedia.org/wiki/Jezioro_Turkusowe, ${ }^{3}[6], \quad{ }^{4}$ http://pl.wikipedia.org/wiki/ Jezioro_Szmaragdowe, ${ }^{5}$ after bathymetry by [6], ${ }^{6}$ coefficient of extension lake = length/average width, ${ }^{7}$ development of shoreline $=$ length of shoreline $/(2 \cdot \sqrt{\pi \cdot \text { area }}),{ }^{8}$ average depth $=$ capacity/area, ${ }^{9}$ relatively depth $=$ max. depth $\sqrt{\text { area }},{ }^{10}$ coefficient of depth $=$ average depth/max. depth

If the ecosystems of chalk lakes really are "resistant" to eutrophication - what could be prove on the basic trophy changes investigative in considerable time interval - then remained to explain mechanism of process phosphorus fixation. For example, considering on limitations of solid surface of chalk bottom, which the sorption abilities will be decrease witch the time flow - the "resistant" with the time flow will be decrease gradually.

In order to determine whether the ecosystems of "chalk lakes" are truly "resistant" to eutrophication - and if so, why - relevant long-term research referring to these ecosystems 
should have been undertaken, among others adequate long-term analysis of surface water quality.

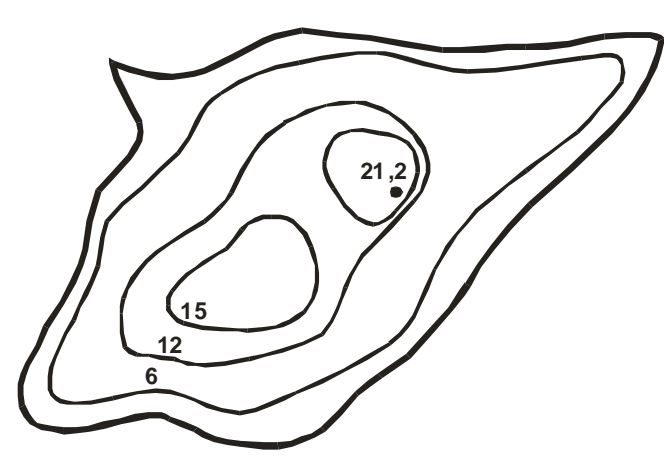

Turkusowe Lake

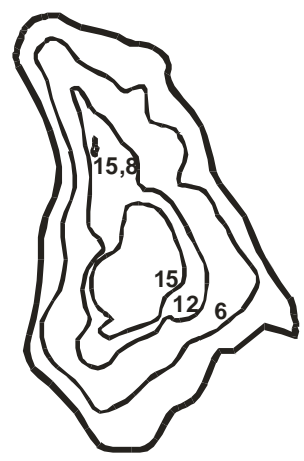

Szmaragdowe Lake
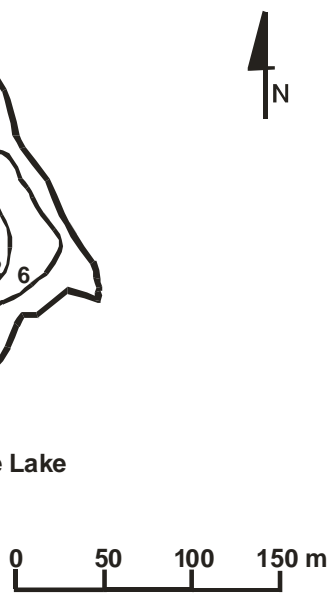

Fig. 1. Turkusowe Lake [3] and Szmaragdowe Lake - bathymetry [6]

In this paper are presented the findings of surface water quality analyses of the Turkusowe Lake being carried out by the authors in 1999-2010 which are compared with available results of earlier studies being conducted since 1986, offering the same a possibility to make an attempt at learning whether the quality of surface water of the Turkusowe Lake was stabilised or time-variable and what processes could induce changes in the ecosystem of this lake in the quarter-century 1986-2010.

\section{Characteristics of the Turkusowe Lake}

The Turkusowe lake (Figs. 1 and 2) is a water reservoir which was formed by flooding a chalk excavation peat after the Second World War where marls, being found in Cretaceous marl xenoliths, had been won for production of cement in a non-existent cement mill situated close to the excavation pit in the village of Wapnica until the end of the war. Lake morphometry parameters are presented in Table 1. A characteristic feature of this lake is the lack of developed littoral zone. The lake sides are formed as sharply falling slopes and the depths, $8-10 \mathrm{~m}$ deep, are frequently to be found few or several meters away from them. High, steep shores, reaching 20-30 m above sea level, surround the Turkusowe Lake from all sides, except short shore sections from the north-east and the north-west, which causes that part of the lake surface is being shaded at least for part of the day and distinctly reduces water mixing by winds, inducing maintenance of vertical and horizontal stratification of water masses for most of the year [3]. It seems that the surface and the benthic waters of the Turkusowe Lake may mix together only in late autumn or even at the beginning of winter before icing it over. 


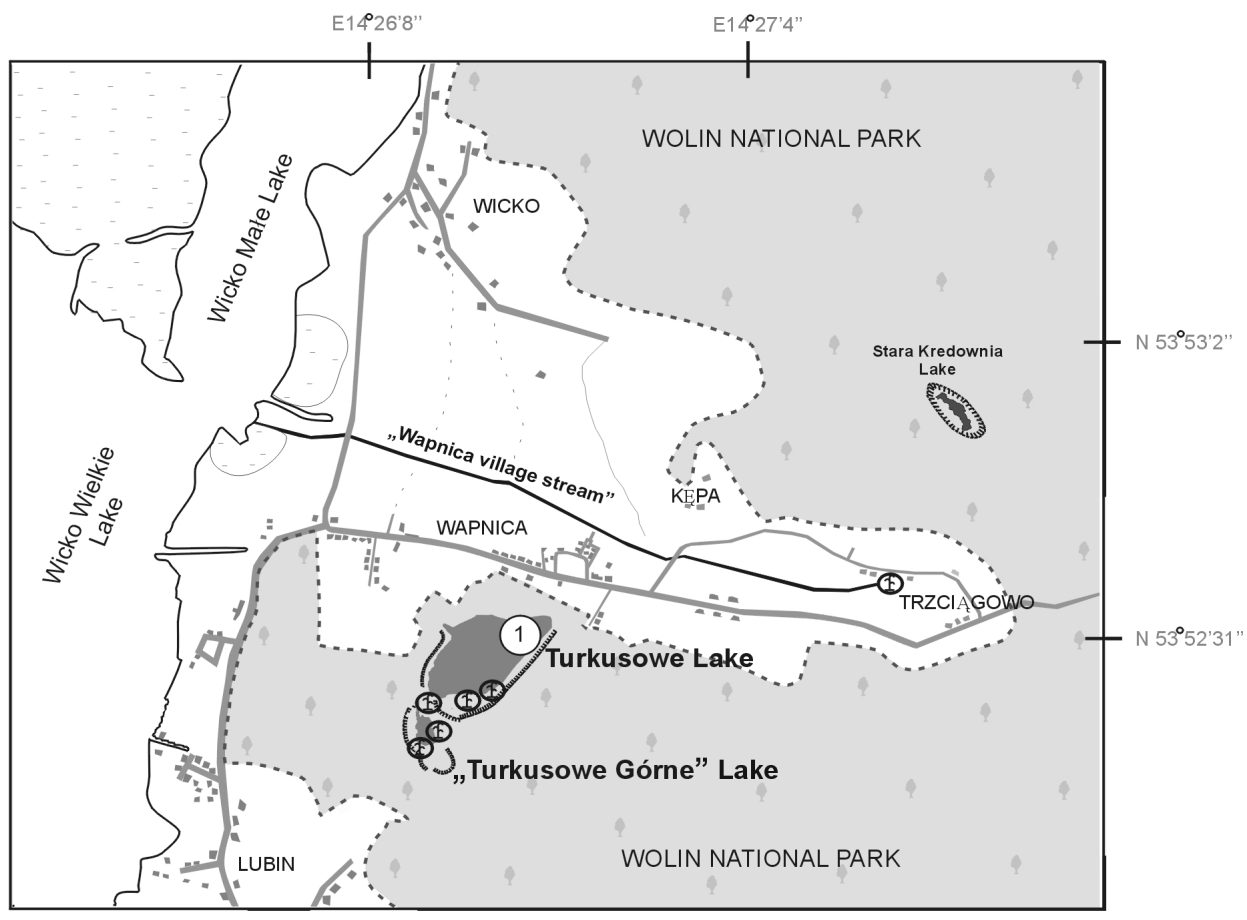

\section{LEGEND}
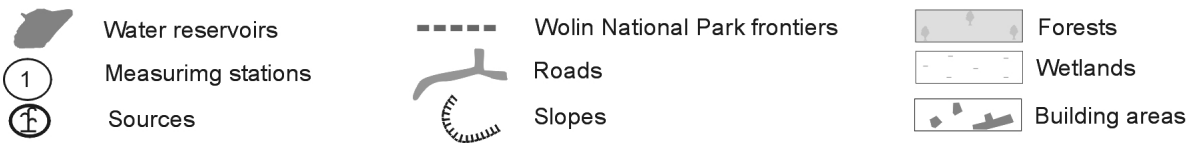

Fig. 2. Turkusowe Lake in the Wolin National Park after [7] with changes

Nevertheless, due to differences in the density of the surface and the near-bottom waters, it is probable that these waters do not mix for the whole year. Therefore, one might assume that the waters in this percolates most probably through more permeably water reservoir are practically two separate quasi-ecosystems of surface water and benthic water, divided by the metalimnion. The lake is being fed by atmospheric precipitation in the form of surface flow and the flow of subsoil waters, part of which flow down to it from numerous sources gushing at the base of heights as well as by the waters flowing from so called Upper Turkusowe Lake, which is also being fed only by rain and subsoil waters. Part of the sources gushing from under the heights is fed by subsoil waters being polluted with faeces, flowing out probably from the buildings in the village of Lubin. A separate problem is discharge of municipal pollution through sewer pipes, being illegally installed in a hard to reach area, draining sewage effluents from private premises situated on the western shore of the lake in the village of Wapnica, just outside the limits of the Wolin National Park. Excess water from the Turkusowe Lake soil layers adhering to the lake from the north-western side towards the Wicko Lake [7]. 


\section{Material and methods}

The analyses of water quality of the Turkusowe Lake was carried out in 1999-2010 in April-October vegetation seasons, collecting water samples from the lake in arbitrary chosen times. Water samples for analyses were drawn from the surface layer of water (ca. $0.5 \mathrm{~m}$ below the water mirror) by means of the Patalas trap at a sampling station situated in the north-east part the lake. At the place of sample collection, water temperature, $\mathrm{pH}$, Eh and SEC were determined in the waters being drawn, as well as their alkalinity. The water samples were collected to determine dissolved oxygen concentration and $\mathrm{BOD}_{5}$. The water samples collected for laboratory analyses were fixed. All determinations being performed, particularly dissolved $\mathrm{O}_{2}$ concentration (DO), COD-Cr, COD-Mn and $\mathrm{BOD}_{5}$ values, and concentrations of $\mathrm{NO}_{3}^{-}, \mathrm{NO}_{2}^{-}, \mathrm{NH}_{4}^{+}$, TN, SRP, TP and concentrations of $\mathrm{Ca}^{2+}, \mathrm{Mg}^{2+}, \mathrm{Cl}^{-}$, $\mathrm{SO}_{4}{ }^{2-}$, as well as total concentrations of $\mathrm{Fe}$ and $\mathrm{Mn}$, were made, except Eh determination, according to the analytical procedures [8]. Water saturation by $\mathrm{O}_{2}$ of the waters under analysis was calculated upon the determined values of dissolved oxygen concentrations and water sample temperature based on the data referring to the values of oxygen solubility in pure water at the temperature of lake water [9]. The redox potential was determined according to the procedure described by [10].

Collections of individual test results of water quality indicators collected during study period - in the years 1999-2010, supplemented by available literature data from the years 1986-1988 and 1993-1994 are presented in the form of combined sets of results. In order to determine the variability of water quality studied parameters general statistical characteristics of the data collected were prepared. On the other hand, in order to discern changes in the value of individual indicators over time - were tested by calculating statistically significant correlation equations describing the dependence of the individual water quality indices of the sampling terms. Calculations were performed using a demonstration version of the Statgraphics Centurion XVI program. All calculations were performed at a significance level $\alpha=0.05$. The significance of the correlation calculated further evaluated by comparing them with the defined critical values of the correlation coefficients for the $n$-number of measurements based on the respective values of the coefficients two sided Student's t-test, according to [11].

\section{Results and discussion}

Results of the analyses being carried out in 1999-2010, together with the findings of earlier studies, are presented as statistical characteristics of individual sets of test results of water quality indices are presented in Table 2, while statistically significant regression equation defining the relationship of these indicators-which changes are correlated with the dates of measurement - are shown in Table 3. Graphical presentation of the different regression equations were applied to the corresponding graphs on Figures 3-5.

As regards water saturation by $\mathrm{O}_{2}$ in the Turkusowe Lake in this time period, it is apparent from the data presented in Figure 3 that the waters of the Turkusowe Lake happened to be saturated by $\mathrm{O}_{2}$ more than $100 \%$ only in certain vegetation seasons in the 80 's, and incidentally in 2000, while ranging 80-100\% in other years, especially after 2000. Sometimes, water saturation by $\mathrm{O}_{2}$ decreased to approximately $30 \%$, which was observed for example - in 2005. The $\mathrm{pH}$ value of the Turkusowe Lake waters varied in the quarter-century from approximately 7.00 to about 8.70 and was relatively stabilised. 
Table 2

Statistical characteristic of the results of investigated surfaces water quality indices of Turkusowe Lake. Data for years: 1986-1987 [2], 1988 [3], 1993-1994 - unpublished data of authors of this work, 1999-2010 - data of this work. The table contains the following information : $n_{\text {data }}$ - number of analysed data, minimum values $\left(x_{\min }\right)$, average $(\bar{x})$, median $(\tilde{x})$, maximum values $\left(x_{\max }\right)$ lower and upper quartile, standard deviation $(S D)$ and coefficient of variation $(\mathrm{CV})$

\begin{tabular}{|c|c|c|c|c|c|c|c|c|c|c|c|}
\hline No & $\begin{array}{c}\text { Water quality indices } \\
\text { (units) }\end{array}$ & $n_{\text {data }}$ & $x_{\min }$ & $\bar{x}$ & $\tilde{x}$ & $x_{\max }$ & $\begin{array}{c}\text { Lower } \\
\text { Quar- } \\
\text { tile }\end{array}$ & $\begin{array}{c}\text { Upper } \\
\text { Quar- } \\
\text { tile }\end{array}$ & $S D$ & $C V$ & Data for years \\
\hline \multicolumn{12}{|c|}{ I.1. General parameters } \\
\hline 1 & $\begin{array}{c}\mathrm{pH} \\
\text { [pH units] }\end{array}$ & 32 & 7.00 & 7.85 & 7.91 & 8.70 & 7.51 & 8.20 & 2.11 & 0.28 & $\begin{array}{c}1986-1988,1993, \\
1994,1999-2010 \\
\end{array}$ \\
\hline 2 & $\begin{array}{c}\mathrm{Eh} \\
{[\mathrm{mV}]}\end{array}$ & 16 & 42 & 389 & 391 & 522 & 353 & 467 & 123 & 0.38 & $1994,2000-2010$ \\
\hline 3 & $\begin{array}{c}\mathrm{COD}-\mathrm{Cr} \\
{\left[\mathrm{mg} \mathrm{O}_{2} \cdot \mathrm{dm}^{-3}\right]}\end{array}$ & 10 & 17.4 & 21.9 & 22.0 & 25.0 & 19.9 & 24.3 & 0.6 & 0.41 & $2005-2010$ \\
\hline 4 & $\begin{array}{c}\text { COD-Mn } \\
{\left[\mathrm{mg} \mathrm{O}_{2} \cdot \mathrm{dm}^{-3}\right]}\end{array}$ & 27 & 2.6 & 5.5 & 5.0 & 11.1 & 4.0 & 6.4 & 2.5 & 0.11 & $\begin{array}{c}1986-1988,1994 \\
1999-2010\end{array}$ \\
\hline 5 & $\begin{array}{c}\mathrm{BOD}_{5} \\
{\left[\mathrm{mg} \mathrm{O}_{2} \cdot \mathrm{dm}^{-3}\right]}\end{array}$ & 13 & 0.6 & 1.6 & 1.7 & 2.6 & 1.0 & 2.0 & 2.9 & 0.32 & $2005-2010$ \\
\hline 6 & $\begin{array}{c}\text { Water saturation } \\
\text { by } \mathrm{O}_{2}[\%]\end{array}$ & 25 & 27.8 & 83.0 & 87.0 & 121.6 & 79.0 & 90.1 & 0.4 & 0.05 & $\begin{array}{l}1986-1987, \\
1993-1994, \\
2000-2010\end{array}$ \\
\hline \multicolumn{12}{|c|}{ I.2. Biogenic substances } \\
\hline 7 & $\begin{array}{c}\mathrm{NO}_{3}^{-} \\
{\left[\mathrm{mg} \mathrm{N}-\mathrm{NO}_{3} \cdot \mathrm{dm}^{-3}\right]}\end{array}$ & 32 & 0.01 & 0.07 & 0.04 & 0.19 & 0.01 & 0.12 & 0.06 & 0.89 & \multirow{3}{*}{$\begin{array}{c}1986-1988,1993, \\
1994,1999-2010\end{array}$} \\
\hline 8 & $\begin{array}{c}\mathrm{NO}_{2}^{-} \\
{\left[\mathrm{mg} \mathrm{N}-\mathrm{NO}_{2} \cdot \mathrm{dm}^{-3]}\right]}\end{array}$ & 32 & $<0.001$ & 0.0138 & 0.006 & 0.094 & 0.001 & 0.010 & 0.022 & 1.56 & \\
\hline 9 & $\begin{array}{c}\mathrm{NH}_{4}^{+} \\
{\left[\mathrm{mg} \mathrm{N}^{+} \mathrm{NH}_{4} \cdot \mathrm{dm}^{-3}\right]}\end{array}$ & 31 & $<0.01$ & 0.08 & 0.07 & 0.26 & 0.01 & 0.15 & 0.08 & 0.88 & \\
\hline 10 & $\begin{array}{c}\mathrm{TN} \\
{\left[\mathrm{mg} \mathrm{N}^{-3} \mathrm{dm}^{-3}\right]}\end{array}$ & 10 & 0.23 & 0.42 & 0.42 & 0.60 & 0.38 & 0.48 & 0.11 & 0.25 & $2005-2010$ \\
\hline 11 & $\begin{array}{c}\mathrm{SRP} \\
{\left[\mathrm{mg} \mathrm{PO}_{4} \cdot \mathrm{dm}^{-3}\right]}\end{array}$ & 32 & $<0.01$ & 0.17 & 0.10 & 0.83 & 0.01 & 0.26 & 0.19 & 1.11 & $\begin{array}{c}1986-1988,1993, \\
1994,1999-2010 \\
\end{array}$ \\
\hline 12 & $\begin{array}{c}\mathrm{TP} \\
{\left[\mathrm{mg} \mathrm{PO}_{4} \cdot \mathrm{dm}^{-3}\right]} \\
\end{array}$ & 14 & 0.08 & 0.73 & 0.72 & 1.26 & 0.58 & 0.91 & 0.33 & 0.44 & 2004-2010 \\
\hline \multicolumn{12}{|c|}{ I.3. Mineralization indices } \\
\hline 13 & $\begin{array}{c}\mathrm{SEC} \\
{\left[\mu \mathrm{S} \cdot \mathrm{cm}^{-1}\right]}\end{array}$ & 17 & 102 & 295 & 335 & 580 & 102 & 422 & 168 & 0.57 & $\begin{array}{c}1986-1988, \\
1993-1994, \\
1999-2009\end{array}$ \\
\hline 14 & $\begin{array}{c}\mathrm{Ca}^{2+} \\
{\left[\mathrm{mg} \mathrm{Ca} \cdot \mathrm{dm}^{-3}\right]}\end{array}$ & 20 & 42 & 70 & 65 & 132 & 60 & 69 & 21 & 0.30 & \multirow{2}{*}{$\begin{array}{c}1993,1994, \\
2000-2010\end{array}$} \\
\hline 15 & $\begin{array}{c}\mathrm{Mg}^{2+} \\
{\left[\mathrm{mg} \mathrm{Mg} \cdot \mathrm{dm}^{-3}\right]}\end{array}$ & 20 & 4 & 17 & 18 & 35 & 11 & 23 & 8 & 0.47 & \\
\hline 16 & $\begin{array}{c}\mathrm{Cl}^{-} \\
{\left[\mathrm{mg} \mathrm{Cl} \cdot \mathrm{dm}^{-3}\right]}\end{array}$ & 30 & 17 & 37 & 37 & 62 & 23 & 49 & 14 & 0.39 & \multirow{2}{*}{$\begin{array}{c}1986-1988,1993, \\
1994,1999-2010\end{array}$} \\
\hline 17 & $\begin{array}{c}\mathrm{SO}_{4}{ }^{2-} \\
{\left[\mathrm{mg} \mathrm{SO}_{4} \cdot \mathrm{dm}^{-3}\right]}\end{array}$ & 30 & 14 & 53 & 50 & 147 & 36 & 70 & 27 & 0.51 & \\
\hline 18 & $\begin{array}{c}\text { Total alkalinity } \\
{\left[\mathrm{mmol} \mathrm{HCl} \cdot \mathrm{dm}^{-3}\right]}\end{array}$ & 29 & 1.4 & 9.76 & 2.8 & 102.0 & 2.5 & 3.3 & 25.5 & 2.61 & $\begin{array}{c}1986-1988, \\
1993-1994, \\
1999-2009\end{array}$ \\
\hline 19 & $\begin{array}{c}\text { Total Fe } \\
{\left[\mathrm{mg} \mathrm{Fe} \cdot \mathrm{dm}^{-3}\right]}\end{array}$ & 29 & $<0.01$ & 0.19 & 0.09 & 0.90 & 0.03 & 0.35 & 0.23 & 1.16 & $\begin{array}{c}1986-1988,1994, \\
1999-2010\end{array}$ \\
\hline 20 & $\begin{array}{c}\text { Total Mn } \\
{\left[\mathrm{mg} \mathrm{Mn} \cdot \mathrm{dm}^{-3}\right]}\end{array}$ & 16 & 0.03 & 0.15 & 0.16 & 0.27 & 0.07 & 0.20 & 0.08 & 0.53 & $2000-2010$ \\
\hline
\end{tabular}


Table 3

Regression equations showing the statistical importance relationship between values of selected water indices ie $y$ - and $\tau$ - ie date of water sampling for analysis presented as fraction of years (noted from 0 to 24 - from beginning of 1986 to end of 2010)

\begin{tabular}{|c|c|c|c|c|c|c|}
\hline \multirow[t]{2}{*}{ No. } & \multirow{2}{*}{$\begin{array}{l}\text { Water quality } \\
\text { indices (units) }\end{array}$} & \multirow{2}{*}{$\begin{array}{l}\text { Form of the } \\
\text { equation }\end{array}$} & \multirow{2}{*}{$\begin{array}{c}\text { Calculated regression } \\
\text { equation }\end{array}$} & \multirow{2}{*}{$\begin{array}{l}\text { Significance level of the } \\
\text { coefficients in equation }\end{array}$} & \multicolumn{2}{|c|}{$\begin{array}{c}\text { Model fitting } \\
\text { factors }\end{array}$} \\
\hline & & & & & $r^{*}$ & SEE \\
\hline 1 & $\begin{array}{c}\text { Water saturation by } \\
\mathrm{O}_{2} \\
{[\%]}\end{array}$ & $y=\mathrm{a}_{0}+\mathrm{a}_{1} \cdot \tau$ & $\begin{array}{c}y=(99.5 \pm 6.3)- \\
\quad(1.3 \pm 0.4) \cdot \tau\end{array}$ & $\begin{array}{l}\alpha_{\mathrm{a} 0}=0.0000 \\
\alpha_{\mathrm{a} 1}=0.0045\end{array}$ & -0.55 & 17.7 \\
\hline 2 & $\begin{array}{c}\mathrm{NO}_{3}^{-} \\
{\left[\mathrm{mg} \mathrm{N}-\mathrm{NO}_{3} \cdot \mathrm{dm}^{-3}\right]}\end{array}$ & $y=\mathrm{a}_{0}+\mathrm{a}_{1} \cdot \tau^{2}$ & $\begin{array}{c}y=(0.02 \pm 0.01)+ \\
(0.2 \pm 0.03) \cdot 10^{-3} \cdot \tau^{2}\end{array}$ & $\begin{array}{l}\alpha_{\mathrm{a} 0}=0.1382 \\
\alpha_{\mathrm{a} 1}=0.0000\end{array}$ & 0.77 & 0.04 \\
\hline 3 & $\begin{array}{c}\mathrm{SRP} \\
{\left[\mathrm{mg} \mathrm{PO}_{4} \cdot \mathrm{dm}^{-3}\right]}\end{array}$ & $y=\mathrm{a}_{0}+\mathrm{a}_{1} \cdot \tau^{2}$ & $\begin{array}{l}y=(0.04 \pm 0.04)+ \\
(0.6 \pm 0.1) \cdot 10^{-3} \cdot \tau^{2}\end{array}$ & $\begin{array}{l}\alpha_{\mathrm{a} 0}=0.3617 \\
\alpha_{\mathrm{a} 1}=0.0001\end{array}$ & 0.64 & 0.14 \\
\hline 4 & $\begin{array}{c}\mathrm{Cl}^{-} \\
{\left[\mathrm{mg} \mathrm{Cl} \cdot \mathrm{dm}^{-3}\right]}\end{array}$ & $y=\mathrm{a}_{0}+\mathrm{a}_{1} \cdot \tau$ & $\begin{array}{c}y=(57.8 \pm 2.0)- \\
(1.6 \pm 0.1) \cdot \tau\end{array}$ & $\begin{array}{l}\alpha_{\mathrm{a} 0}=0.0000 \\
\alpha_{\mathrm{a} 1}=0.0000\end{array}$ & -0.92 & 6.0 \\
\hline 5 & $\begin{array}{c}\mathrm{SO}_{4}{ }^{2-} \\
{\left[\mathrm{mg} \mathrm{SO}_{4} \cdot \mathrm{dm}^{-3}\right]}\end{array}$ & $y=\mathrm{a}_{0}+\mathrm{a}_{1} \cdot \tau$ & $\begin{array}{c}y=(24.1 \pm 6.4)+ \\
(2.3 \pm 0.4) \cdot \tau\end{array}$ & $\begin{array}{l}\alpha_{\mathrm{a} 0}=0.0008 \\
\alpha_{\mathrm{a} 1}=0.0000\end{array}$ & 0.72 & 19.4 \\
\hline 6 & $\begin{array}{c}\text { Total Fe } \\
{\left[\mathrm{mg} \mathrm{Fe} \cdot \mathrm{dm}^{-3}\right]}\end{array}$ & $y=\mathrm{a}_{0}+\mathrm{a}_{1} \cdot \tau^{2}$ & $\begin{array}{c}y=(0.04 \pm 0.05)+ \\
(0.60 \pm 0.20) \cdot 10^{-3} \cdot \tau^{2}\end{array}$ & $\begin{array}{l}\alpha_{\mathrm{a} 0}=0.4676 \\
\alpha_{\mathrm{a} 1}=0.0008\end{array}$ & 0.58 & 0.18 \\
\hline
\end{tabular}

*All values of $\mathrm{r}$ in this column are the absolute values greater than the limit values of $\mathrm{r}$ calculated for the appropriate number of measurements $\mathrm{n}$ in the range $n=23-30$ taken for calculation of individual correlations, respectively, calculated on the basis of the two-sided Student's t-test at a significance level of 0.05 - that documents further the statistical significance of the calculated regression equations.

Changes in the Eh values were more puzzling. Provided that the Eh values being measured in 1995 showed the redox potential of the waters under analysis to be formed by a redox pair $\mathrm{Fe}^{2+} / \mathrm{Fe}^{3+}$, those from 2000 onward clearly indicate that the redox potential of the analysed waters was formed by redox pairs $\mathrm{NH}_{4}{ }^{+} / \mathrm{NO}_{2}{ }^{-}, \mathrm{NH}_{4}{ }^{+} / \mathrm{NO}_{3}{ }^{-}$and $\mathrm{NO}_{2}{ }^{-} / \mathrm{NO}_{3}{ }^{-}$ [10], which is evidence of the maintenance of sufficiently high concentrations of $\mathrm{NH}_{4}^{+}$, $\mathrm{NO}_{2}{ }^{-}$and $\mathrm{NO}_{3}{ }^{-}$ions in the reservoir of water. The waters being analysed in 2005-2010 contained increasingly more organic matter when evaluated according to the COD-Cr values, raising from approximately 17 to about $25 \mathrm{mg} \mathrm{O}_{2} \cdot \mathrm{dm}^{-3}$. The quantities of easily oxidising organic matter, being determined according to the COD-Mn values, were relatively stabilised during the whole quarter-century under discussion and amounted to approximately 4.0-7.0 $\mathrm{mg} \mathrm{O}_{2} \cdot \mathrm{dm}^{-3}$, except for the values that incidentally deviated from this range. On the other hand, the $\mathrm{BOD}_{5}$ values were low. The collected data, although relatively few, are the proof that the waters under analysis contained small quantities of biodegradable organic matter, or that microorganisms being able to decompose the organic matter contained in the body of water were very few or not very active. Changes in the concentrations of biogenic substances, especially mineral nitrogen compounds, indicate quite distinctly that the surface waters in the lake were clearly more abundant in mineral nitrogen compounds $\left(\mathrm{NO}_{3}{ }^{-}\right.$concentration increased to ca. $19 \mathrm{mg} \mathrm{N} \cdot \mathrm{dm}^{-3}$, whereas that of $\mathrm{NH}_{4}^{+}$to ca. $26 \mathrm{mg} \mathrm{N}-\mathrm{NH}_{4} \cdot \mathrm{dm}^{-3}$ ), although relatively high $\mathrm{NO}_{3}^{-}$and $\mathrm{NH}_{4}^{+}$concentrations had occurred in earlier years. In general, the values of mineral nitrogen compounds concentrations were not record high ones when compared to the waters of other lakes [12]. The abundance of water in SRP changed similarly in this time period, which is quite clear evidence of the increase in the trophic level after year 2000. In [7], attention was drawn to the occurrence of considerable concentrations of SRP and TP in the water of sources 
feeding the Turkusowe Lake, which is undoubtedly a consequence of draining the waste-waters being abundant in phosphates from detergents to the catchment basin in the alimentation zone of source waters feeding the Turkusowe Lake. The data concerning TP concentrations in the waters of the Turkusowe Lake from 2004-2010 indicate that the quantity of organic matter slowly increased with time, showing thus similar trends of changes as the COD-Cr values. Nevertheless, the absolute values of TP concentrations, like those of TN, should be evaluated as relatively small [12]. Taking advantage of the fact that certain part of the findings of 1999-2010 represents the results if studies from early spring, an attempt was made at determining the trophic level of the Turkusowe Lake waters in that time based on the values of determined TP concentrations and the criteria given by [13]. These data show that the trophic level of the surface water of the Turkusowe Lake slowly increased and should have been classified as meso-eutrophic ones by the end of the research period. Therefore, it can be expected that because of increased anthropogenic pressure the processes limiting earlier development of surface water trophy in the lake stopped in a way being effective - when compared to the earlier time period - and stopped protecting the ecosystem from eutrophication. Nevertheless, in view of the values of such water quality parameters as water saturation by $\mathrm{O}_{2}, \mathrm{pH}, \mathrm{COD}-\mathrm{Cr}$ and $\mathrm{TN}$ and $\mathrm{TP}$, as well as concentrations of mineral nitrogen compounds and SRP, it can be assumed that development of eutrophication processes in the ecosystem of the Turkusowe Lake was still relatively small. This specific feature of the Turkusowe Lake which is its ability to maintain low trophy level, ignoring even the fact that the lake has a lake basin being built of $\mathrm{CaCO}_{3}$ capable of permanently binding phosphorus in the form of sparingly soluble compounds, is not strange given that the Turkusowe Lake is a relatively deep water reservoir. Admittedly the ratio of the epilimnion volume to that of hypolimnion for this lake is greater than 1 , but it should not be a number significantly greater than one, which means that in accordance with the Thienemann's rule, according to which the lakes with the above-mentioned ratio being $<1$ are rather oligotrophic ones [14], the Turkusowe Lake should be resistant to eutrophication. The occurrence of well expressed eutrophication phenomena, specifically phytoplankton bloom in this case, may be treated as a consequence of intensified anthropogenic pressure, especially of increased discharge of municipal sewage directly to the lake in last years and draining the waste-waters to the ground in the alimentation zone of water sources feeding the Turkusowe Lake [7]. Obviously, the presence of $\mathrm{CaCO}_{3}$ deposits at the bottom of the lake has been responsible for the sorption and binding of part of SRP as well as organic compounds from the reservoir of water [15-17]. Nevertheless, in the opinion of the authors of this paper, the presence of $\mathrm{CaCO}_{3}$ at the bottom of lake basin does not automatically cause "by itself" the surface water to be resistant to eutrophication under conditions of permanent stratification of surface and near-bottom waters being maintained practically constantly. Undoubtedly, the binding of phosphorus, as well as magnesium (as below), being contained in the surface water, by solid $\mathrm{CaCO}_{3}$ takes place at the bottom of the lake. But we do not know so far what is the mechanism of binding SRP and $\mathrm{Mg}^{2+}$ being contained in the surface water by $\mathrm{CaCO}_{3}$ occurring at the bottom of the lake under conditions of water stratification being maintained practically for the whole year. Assuming that the binding of SRP and $\mathrm{Mg}^{2+}$ by $\mathrm{CaCO}_{3}$ takes place, the rate of these processes is obviously reduced, which causes the "inhibition" of increase in the concentrations of the above-mentioned especies under conditions of the supply of phosphorus and magnesium compounds not to compensate fully the rate of their supply to ecosystem. Very 
characteristic and attesting to the specificity of the water reservoir under analysis are the findings referring to determined mineral macro- and micro-elements. For example, the fact that $\mathrm{Ca}^{2+}$ concentrations are decidedly lower from $\mathrm{Ca}^{2+}$ ones being in equilibrium with $\mathrm{CaCO}_{3}$ (s) [18], even in the waters with so small ionic strength as those of the Turkusowe Lake. Nevertheless, an incidental occurrence high $\mathrm{Ca}^{2+}$ concentrations appears to be evidence of incidental mixing of the surface water with the near-bottom one being abundant in $\mathrm{Ca}^{2+}$ by virtue of interaction with $\mathrm{CaCO}_{3}$. On the other hand, a relatively slow but clear increase in the $\mathrm{Mg}^{2+}$ concentration appears to be evidence of the enrichment of lake's surface water with magnesium, most probably derived from the organic matter of plant origin being decomposed in the lake, which should be "inhibited" by $\mathrm{CaCO}_{3}$ dolomitisation process in suspended matter and bottom sediments, taking place under conditions of the mixing of surface near-bottom waters. A possibility of this process taking place was highlighted by [5]. However, a decrease in $\mathrm{Cl}^{-}$concentrations, which had been maintained at relatively high levels in the past probably owing to deposition of sea-water aerosols within the area of lake's catchment basin, may be explained by changes in atmospheric circulation from previously prevailing north-westerly one to the circulation from the southern directions [19] and freshening of the lake by rain-waters. Also $\mathrm{SO}_{4}{ }^{2-}$ concentrations, which are being brought together with sea-water aerosols eg [20] and volatile sulphur compounds of sea origin [21], should have changed like those of chlorides. Thus, $\mathrm{SO}_{4}{ }^{2-}$ concentrations should decrease like chloride ones and not increase. The increase in $\mathrm{SO}_{4}{ }^{2-}$ concentrations being observed may be also connected with introduction of protein substances of animal origin to the ecosystem of the lake together with waste-water and - what is more decisive - with deposition of dry $\mathrm{SO}_{2}$, primarily $\mathrm{H}_{2} \mathrm{SO}_{4}$ with acid rains from the clouds moving from the south (consequence of the dominance of southerly wind circulation) and bringing acidic substances being emitted to the atmosphere by the "Police" Chemical Plant near Szczecin and the "Dolna Odra" Power Plant Complex near Gryfino, which was already showed in the papers by [22]. However, the increase in concentrations of sulphate(VI) ions in the Turkusowe Lake should not be connected with infiltration of Jurassic waters [23] and possibly those of the Szczecin Lagoon waters. On the other hand, the increase in total concentrations of $\mathrm{Fe}$ and $\mathrm{Mn}$ is undoubtedly connected with the inflow of subsoil waters from those areas of the catchment basin which are abundant in sands containing iron and manganese. Soil waters, after enriching the soil with the organic matter being introduced to it with waste-water, induce an increase in the abundance of water with soluble compounds of iron and manganese as a consequence of change in the redox status of subsoil waters from oxidation to reduction, which causes an intensified reduction of iron and manganese compounds with high oxidation number and Fe and Mn leaching in the form of more easily leached compounds of iron(II) and manganese(II) [24]. This is due to increasing anthropogenic pressure in the catchment basin, especially draining municipal waste-water to the ground. Relatively high and constantly sustained iron concentrations in the quasi-ecosystem of surface waters may cause that the processes of chemical oxidation of organic matter take place with participation of hydroxyl radicals being generated by iron compounds in the catalytic process known as the Fenton process [25], being found in the this surface water quasi-ecosystem where reduction of iron(III) compounds to iron(II) ones in the presence of organic matter occurs in the euphotic layer [26]. Perhaps this process specifically inhibits the activity of biochemical oxidation of organic matter in the surface 
waters of the Turkusowe Lake and simultaneously contributes to the fact that these waters contain relatively little dissolved organic matter.
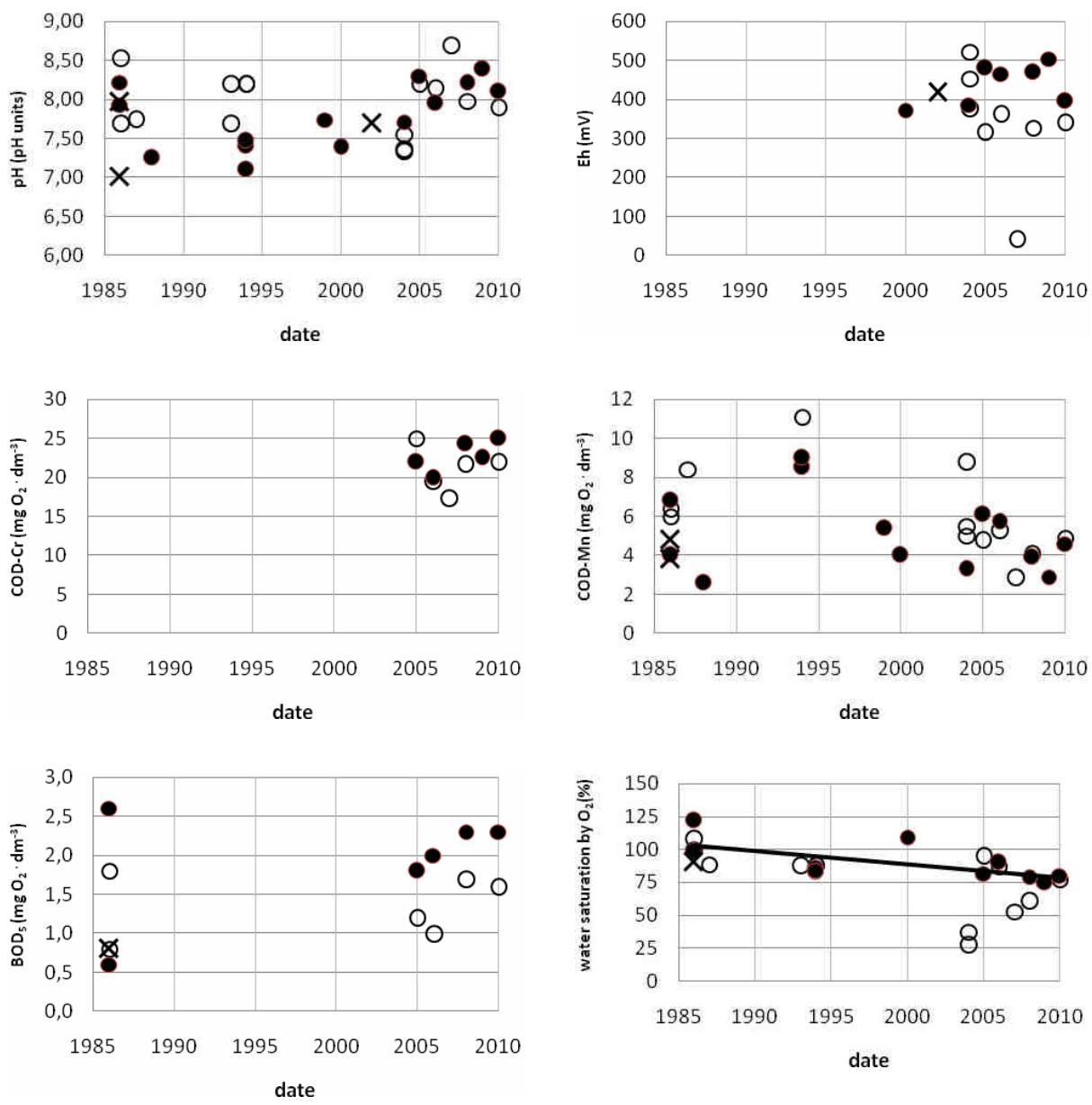

Fig. 3. Turkusowe Lake - surface waters general chemical indices in spring (๑), summer ( ) and autumn (x) in years 1986-2010. Data for years: 1986-1987 [2], 1988 [3], 1993-1994 unpublished data of authors of this work, 1999-2010 - data of this work. Annotation: Some of the figures also show graphically the equation which is statistically significant and presents relationship between the parameter value and the date of measurement (Table 3) 

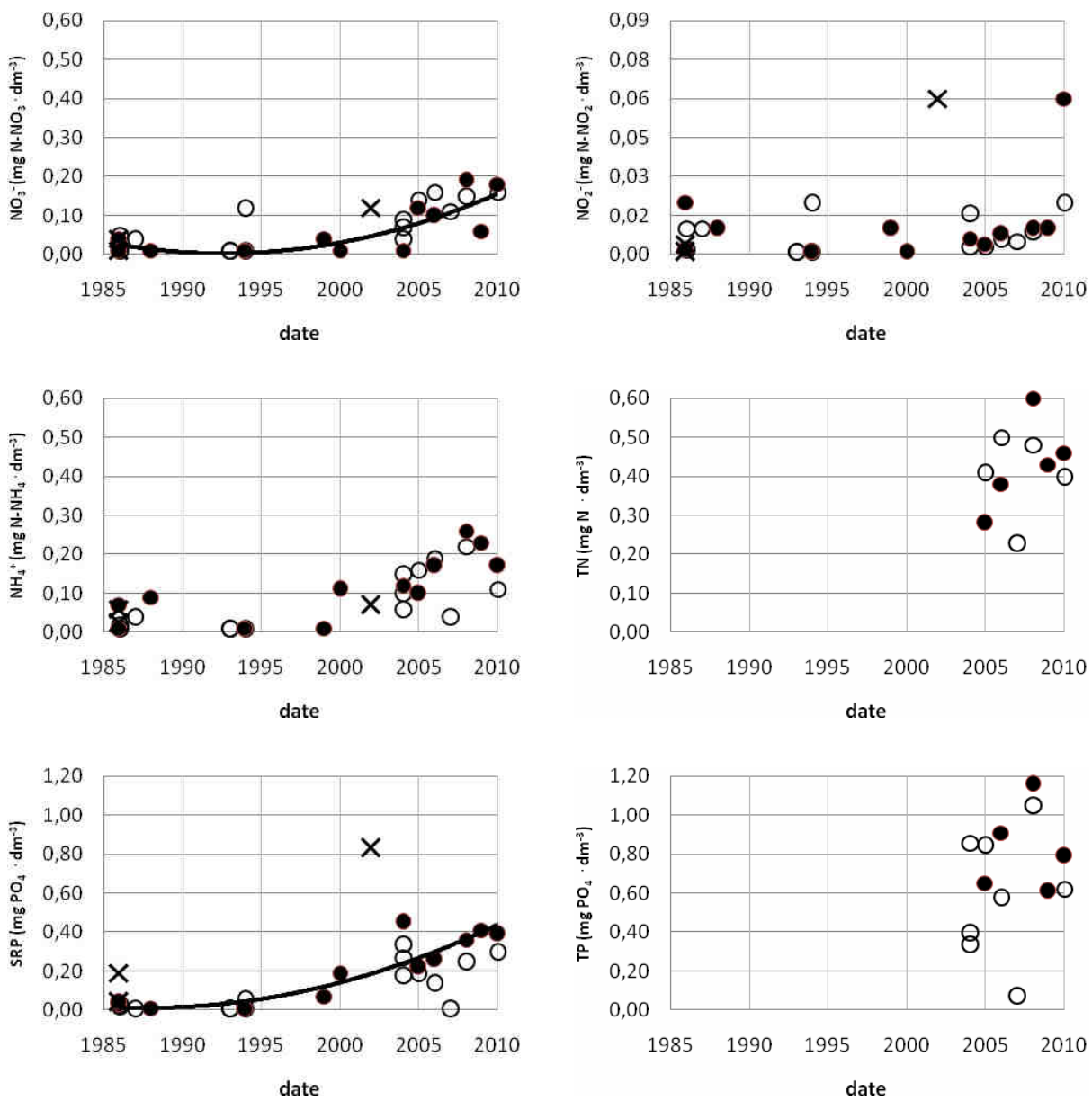

Fig. 4. Turkusowe Lake - surface waters selected indices characterized concentrations in waters of nitrogen and phosphorus substances in spring $(\bullet)$, summer $(\bullet)$ and autumn $(\mathrm{x})$. Data for years: 1986-1987 [2], 1988 [3], 1993-1994 - unpublished data of authors of this work, 1999-2010 data of this work. Annotation: Some of the figures also show graphically the equation which is statistically significant and presents relationship between the parameter value and the date of measurement (Table 3) 

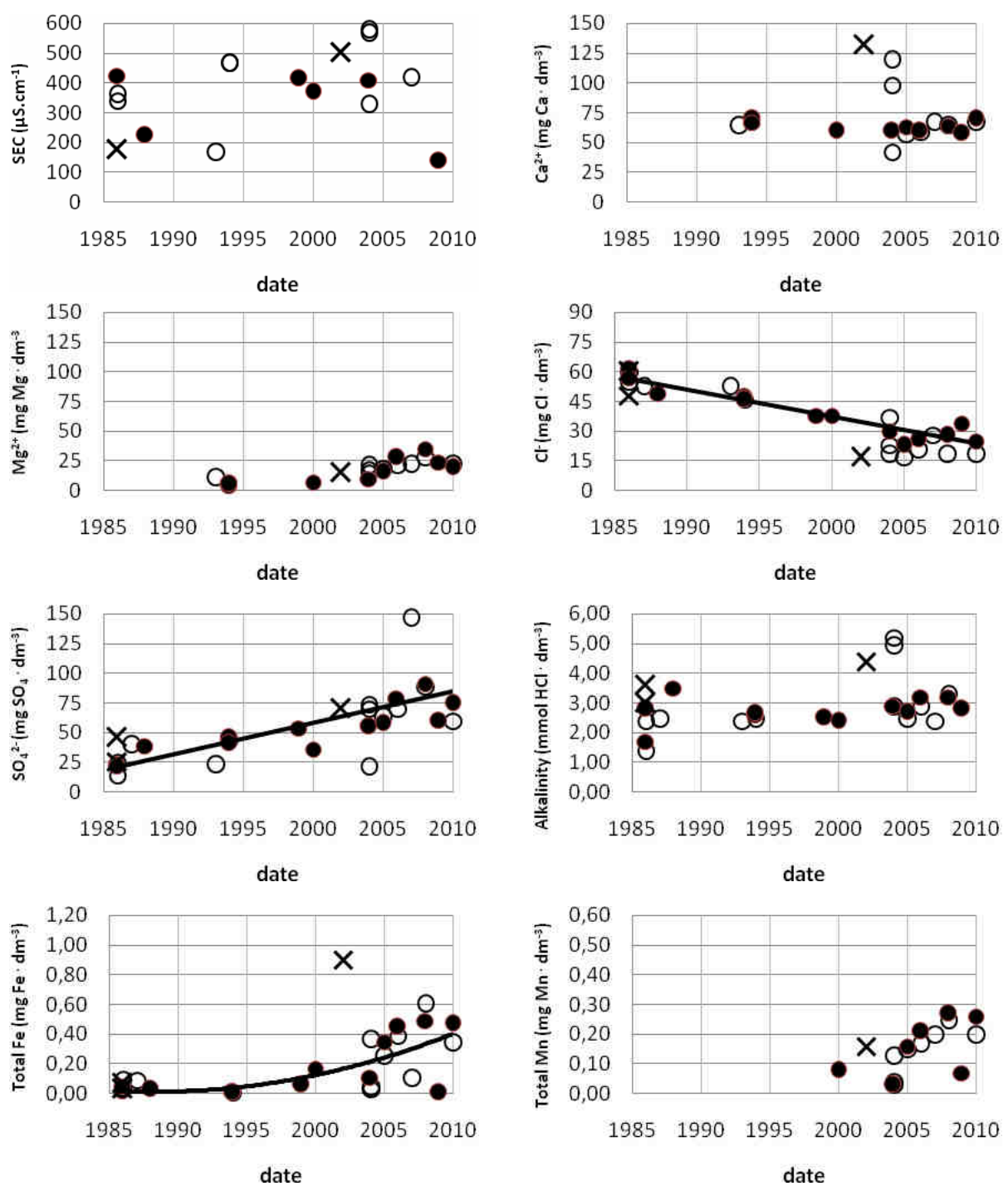

Fig. 5. Turkusowe Lake - surface waters selected mineral macro and micro components of waters environment in spring (०), summer ( ) and autumn (x). Data for years: 1986-1987 [2], 1988 [3], 1993-1994 - unpublished data of authors of this work, 1999-2010 - data of this work. Annotation: Some of the figures also show graphically the equation which is statistically significant and presents relationship between the parameter value and the date of measurement (Table 2)

\section{Conclusions}

The water reservoir in the $\mathrm{CaCO}_{3}$ excavation pit, called the Turkusowe Lake, being situated in the Wolin National Park on the Wolin Island, is characterised by natural 
resistance to eutrophication, like other similar lakes, due to the fact that it is a relatively deep lake without the littoral zone, with steep shores and a large ratio of the hypolimnion volume to the epilimnion volume, which - according to the Thienemann's rule - predestines the trend towards maintenance of oligotrophy, and surrounded by steep, 30-40 m heights that practically limit the wind mixing of waters, which favours the maintenance of their vertical and horizontal stratification, whereas the presence of thick $\mathrm{CaCO}_{3}$ deposits building the compact lake basin certainly favours phosphorus binding in the form of sparingly soluble sediments, although the mechanism of binding the orthophosphates being dissolved in the reservoir of surface water by solid $\mathrm{CaCO}_{3}$ occurring at the bottom of the lake has not been described yet.

Despite the conditions favouring maintenance of oligotrophy, the trophic level of surface water of the Turkusowe Lake in 2005-2010 increased to the state of mesotrophy with distinctive development of eutrophication phenomena, specifically occurrence of weak phytoplankton blooms, due to significant anthropogenic pressure being manifested as direct discharge of municipal sewage to the lake and of waste-water to the soil in the alimentation zone of underground waters feeding this lake.

The state of practically permanent maintenance of low water saturation by $\mathrm{O}_{2}$ of the surface water of the Turkusowe Lake, apart from summer phytoplankton blooms, which is evidence of the prevalence of dissimilation processes over assimilation ones in the lake and the occurrence of significant abundance of the lake's water in colloidal elements and organic matter being found in the form of suspended solids, is alarming.

\section{References}

[1] Kanduč T, Mori N, Kocman D, Stibilj V, Grassa F. Hydrogeochemistry of Alpine springs from North Slovenia: Insights from stable isotopes. Chem Geol. 2012;300-301:40-54. DOI: 10.1016/j.chemgeo.2012.01.012.

[2] Rutkowski D. Badania stopnia zeutrofizowania jezior Wolińskiego Parku Narodowego o różniącej się genezie na przykładzie jeziora Turkusowego i jeziora Gardno. MSc Thesis. Typography. Szczecin: Akademia Rolnicza w Szczecinie; 1987.

[3] Chałupka M, Graf R, Kaniecka D, Wrzesiński D. Batymetria, termika i chemizm wód jeziora Turkusowego. In: Środowisko przyrodnicze i przestrzenna struktura społeczno-ekonomiczna miasta i gminy Międzyzdroje (monografia geograficzna). Kostrzewski A, editor. Poznań: Wyd. UAM; 1989; 231-240.

[4] Raczyńska M, Kubiak J. Hydrochemical conditions in lakes of the „Puszcza Bukowa” Szczecin Landscape Park. Acta Sci Pol. Piscaria. 2003;2(2):91-116.

[5] Poleszczuk G. Równowagi węglanowe w wodach jezior w strefie porwaków kredowych na wyspie Wolin. Parki Nar Rez Przyr. 1994;13:75-84.

[6] Kubiak J, Machula S. Water thermal regimes in selected antropogenic reservoirs in Western Pomerania. Oceanol Hydrobiol Stud. 2013;42(2):155-163. DOI: 10.2478/s13545-013-0069-8.

[7] Poleszczuk G, Bucior A, Grzegorczyk K, Suzin B. Water of springs in Trzciągowska Valley (Buffer protection zone and areas of Wolin National Park) - results of chemical investigations. Ecol Chem Eng. 2005;12:1267-1279.

[8] APHA. Standard methods for examination of water and wastewater. 16th ed. Washington: 1985.

[9] Nemerow NL. Stream, Lake, Estuary and Ocean Pollution. New York: Van Nostrand Reinhold; 1995.

[10] Schüring J, Schulz HD, Fischer WR, Böttcher J, Duijnisveld WHM. Redox. Fundamentals, Processes and Applications. Berlin/Heidelberg: Springer; 2000. DOI: 10.1007/978-3-662-04080-5.

[11] Barragués JI, Morais A, Guisasola J. Probability and statistics - A didactics introduction. Boca Raton (Florida, USA): CRC Press Taylor \& Francis Group; 2014.

[12] Dojlido J, Best GA. Chemistry of Water and Water Pollution. New York: Ellis Horwood Ltd.; 1993.

[13] OECD. Eutrophication of waters: monitoring, assessment and control. Paris: OECD Publications and Information Center; 1982.

[14] Lampert W, Sommer U. Limnoökologie. Stuttgart: Springer; 1999. 
[15] S $\varnothing$ HU, Postma D, Jakobsen R, Larsen F. Sorption of phosphate onto calcite; results from batch experiments and surface complexation modeling. Geochim Cosmochim Acta. 2011;75:2911-2923. DOI: 10.1016/j.gca.2011.02.031.

[16] Wang Q, Li Y. Prosphorus adsorption and desorption behavior on sediments of different origins. J Soils Sediments. 2010;10:1159-1173. DOI 10.1007/s11368-010-0211-9.

[17] Jalail M, Peikam EN. Phosphorus sorption-desorption behaviour of river bed sediments in the Abshineh river, Hamedan, Iran, related to their composition. Environ Monit Assess. 2013;185:537-552. DOI 10,1007/s10661-012-2573-5.

[18] Morse JW, Arvidson RS, Lüttge A. Calcium carbonate formation and dissolution. Chem Rev. 2007;107(2):342-381. DOI: 10.1021/cr050358j.

[19] Girjatowicz JP. The relationship of the North Altanctic Oscillation to water temperature along the southern Baltic Sea Coast. Int J Climatol. 2008;28:1071-1081 DOI: 10,1002/joc.1618.

[20] Plauškaitė K, Ulevicius V, Špirkauskaitė N, Byčenkienė S, Zieliński T, Petelski T, et al. Observations of new particle formation events in the south-eastern Baltic Sea. Oceanologia. 2010;52(1):53-75. DOI:10.5697/oc.52-1.053.

[21] Leck C, Larsson U, Bågander LE, Johansson S, Hajdu S. Dimethyl sulfide in the Baltic Sea: Annual variability in relation to biological activity. J Geophys Res. 2012;95(C3):3353-3363. DOI: 10.1029/JC095iC03p03353.

[22] Poleszczuk G, Jakuczun B. Pomiary suchego depozytu dwutlenku siarki, tlenków azotu, lotnych związków fluoru oraz opadu pyłów w lasach Wolińskiego Parku Narodowego. Ecol Chem Eng. 1996;3:197-211.

[23] Kaczor D. The salinity of groundwater in Mesozoic and Cenozoic aquifers of NW Poland - origin and evolution. Stud Geol Polonica. 2006;126:5-76. http://sgp.ing.pan.p1/126_pdf/SGP126_005-076.pdf.

[24] Koretsky CM, MacLeod A, Sibert RJ, Snyder C. Redox stratification and salinization of three kettle lakes in Southwest Michigan, USA. Water Air Soil Pollut. 2012; 223:1415-1427. DOI: 10.1007/s11270-011-0954-y.

[25] Muruganandham M, Suri RPS, Jafari Sh, Sillanpää M, Lee GJ, Wu JJ, et al. Recent developments in homogeneous Advanced oxidation processes for water and wastewater treatment. Int J Photoenergy. 2014; Article ID 821674, 21 pages. http://dx.doi.org/10.1155/2014/821674.

[26] Meunier L, Laubscher H, Hug SJ, Sulzberger B. Effects of size and origin of natural dissolved organic matter compounds on the redox cycling of iron in sunlit surface waters. Aquat Sci. 2005;67:292-307. DOI: 10.1007/s00027-005-0779-0.

\title{
JEZIORO TURKUSOWE (WYSPA WOLIN, POLSKA) - ZMIANY JAKOŚCI WÓD POWIERZCHNIOWYCH W LATACH 1986-2010
}

\author{
${ }^{1}$ Katedra Chemii i Ochrony Środowiska Wodnego, Wydział Biologii, Uniwersytet Szczeciński \\ ${ }^{2}$ Katedra Zdrowia Publicznego i Opieki Weterynaryjnej, Wydział Higieny Weterynaryjnej i Ekologii \\ Uniwersytet Weterynarii i Nauk Farmaceutycznych w Brnie
}

\begin{abstract}
Abstrakt: Przedstawiono charakterystykę zbiornika wodnego w wyrobisku po kopalni $\mathrm{CaCO}_{3}$, zwanego jeziorem Turkusowym, znajdującego się w Wolińskim Parku Narodowym na wyspie Wolin. Następnie zebrano dostępne wyniki badań jakości wód powierzchniowych tego zbiornika prowadzonych od 1986 roku i wyniki badań własnych prowadzonych od 1999 do 2010 roku - gromadząc materiał badawczy obejmujący ćwierćwiecze 1986-2010. Wykazano, że jezioro Turkusowe jest zbiornikiem odpornym z natury na eutrofizację (ukształtowanie i głębokość misy zbiornika, otoczenie przez przywierające do jeziora wysoczyzny oraz obecność $\mathrm{CaCO}_{3}$ tworzącego misę jeziorną), zaś obserwowany szczególnie w latach 2005-2010 wzrost trofii i rozwój zjawisk eutrofizacyjnych w postaci słabych zakwitów fitoplanktonowych jest związany ze wzrostem antropopresji w postaci bezpośredniego zrzutu ścieków komunalnych do jeziora i wód ściekowych do gleb w strefie alimentacji wód podziemnych zasilających to jezioro. Rozmiary antropopresji były tak znaczne, że zaczęły przeważać nad naturalnymi procesami ograniczającymi wzrost trofii w tym zbiorniku.
\end{abstract}

Słowa kluczowe: jeziora, trofia i eutrofizacja, jeziora kredowe, jezioro Turkusowe, Woliński Park Narodowy 